\title{
Branding the destination versus the place: The effects of brand complexity and identification for residents and visitors
}

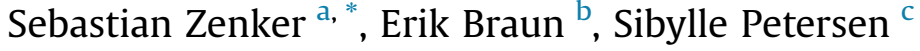 \\ a Department of Marketing, Solbjerg Plads 3C, 3rd Floor, DK-2000 Frederiksberg, Denmark \\ ${ }^{\mathrm{b}}$ Erasmus School of Economics, Erasmus University Rotterdam, Room H16-17, P.O. Box 1738, 3000 DR Rotterdam, The Netherlands \\ ${ }^{\mathrm{c}}$ University of Leuven, Tiensestraat 102, BE-3000 Leuven, Belgium
}

\section{H I G H L I G H T S}

- Residents are an important target group for destination branding, since they, e.g., work as place ambassadors.

- (Destination) branding often simplifies messages, but this could be not effective for complex brands.

- Residents have a wider knowledge of the place and could disagree with a simplified brand.

- For residents, positive place attitude and place behaviour is increased with a higher brand complexity.

- Positive relationship between brand complexity and place attitude and behaviour is stronger for residents than for tourists.

\section{A R T I C L E I N F O}

\section{Article history:}

Received 30 September 2015

Received in revised form

19 September 2016

Accepted 11 October 2016

\section{Keywords:}

Destination branding

Place branding

Brand complexity

Multiple stakeholders

Place identification

Social identity theory

\begin{abstract}
A B S T R A C T
This article contributes to a broader understanding of how the branding of places affects both residents and tourists. While branding often relies on simplified messages, the effectiveness of such strategies for complex brands remains questionable. Residents in particular possess a confounded knowledge of the place and could disagree with simplified destination brands. To test the role of brand complexity for residents and tourists, we conducted two empirical studies $(N=765 ; N=385)$, showing that, for residents, positive place attitude (i.e., place satisfaction, identification, and attachment) and place behaviour (i.e., positive word-of-mouth) increase with a higher brand complexity. The second study shows that the positive relationship of brand complexity is stronger for residents than for tourists, supporting the conclusion that brand complexity is relevant for place brands, but that the place brand for residents requires more complexity than a destination brand, while it imperative that both are integrative parts of an overall brand.
\end{abstract}

() 2016 Elsevier Ltd. All rights reserved.

\section{Introduction}

In response to the increasing competition for tourists, investments, companies, and well-educated residents, place branding has rapidly evolved as a research domain (Gertner, 2011) intended to help cities, regions, and nations become more efficient in their marketing and branding strategies (Braun, 2012; Hanna \& Rowley, 2015). Through place branding, place marketers focus on building strong, favourable place brands that can be communicated to diverse target audiences and stakeholders (Merrilees, Miller, \& Herington, 2012). While place branding often takes the form of

\footnotetext{
* Corresponding author.

E-mail addresses: zenker@placebrand.eu (S. Zenker), braun@ese.eur.nl (E. Braun), sibylle.petersen@psy.kuleuven.be (S. Petersen).
}

destination branding in order to attract tourists (Park \& Petrick, 2006; Qu, Kim, \& Im, 2011), destination branding has also recently widened its focus to include other target groups such as residents (Hanna \& Rowley, 2015; Palmer, Koenig-Lewis, \& Jones, 2013) showing the close relationship of both concepts. Conceptually, destination branding targets solely tourists, while place branding describes the general branding of places for all target groups such as residents, companies and tourists (Kerr, 2006) thus place branding could be understood as the family tree, with destination branding as one of the branches (Zenker \& Braun, 2010). Having said this, in practice it remains questionable if destination branding can be really seen separated from the residential part of the place brand. In reality, destination branding needs the residents (Freire, 2009) and will at the same time also affect the residents' perception.

Furthermore, residents are seen as an important part of the 
tourism business, since they are not only part of the place as such, but also directly benefit from positive developments or perceive the negative social and environmental effects of tourism. Thus, residents' perceptions of tourism and attitudes towards tourists are often the focus of academic tourism studies (Sharpley, 2014). However, little attention has been paid to how place branding (including destination branding) affects both tourists and residents (with the exception of Palmer et al., 2013), especially in light of targeting both groups simultaneously (Hanna \& Rowley, 2015; Zenker \& Beckmann, 2012).

In practice, place marketers try to promote the place to tourists and residents at the same time, aiming to strengthen the current residents' identification with the place and thereby transform them into authentic place ambassadors (Braun, Kavaratzis, \& Zenker, 2013; Palmer et al., 2013; Zenker \& Petersen, 2014). Unfortunately, place and destination marketers often underestimate the difficulties of establishing a place brand (targeting both, tourists and residents alike) by using simplified, corporate branding strategies, since places are highly complex with a great variety of target audiences. For example, the second largest city in The Netherlands, Rotterdam, houses 173 different nationalities (Braun, 2008), to say nothing of the diverse socio-economic classes. This high level of demographical complexity makes it difficult to construct a place brand that is both simple and convincing for the majority of the external and internal target audiences. To add to this challenge, the city targets a wide range of (touristic) target groups, but their perception of a place is often quite different and characterized by simple stereotypes (Zenker \& Beckmann, 2012)—reducing, for example, Paris to a city of arts and love, or Munich to the Oktoberfest and people wearing 'leather trousers'. This differentiated perception of a place by residents and visitors may stem from the general Out-Group Homogeneity Effect. This effect occurs when people commonly perceive their in-group to be more variable (particularly on positive dimensions) in comparison to an outgroup (Mullen \& Hu, 1989).

In cases of high place complexity, the effectiveness of simplified brand messages remains questionable (Anholt, 2009; Qu et al., 2011). Internal target audiences and heavy users have a confounded knowledge of the branded object and could disagree with the simplified brand message. This could result in lower brand identification and less favourable behaviour (e.g., positive word-ofmouth or visiting behaviour).

This research, then, seeks to develop a broader understanding of how place branding affects both residents and tourists, and what role the complexity of such a brand plays in place identification. We will outline the positive outcomes of place identification and how this can be improved through brand complexity (Study 1 ). In a next step, we will take a deeper look at how the identification process differs for residents and tourists (Study 2). In doing so, we try to: (1) translate new content from related disciplines to the field of tourism; (2) put a spotlight on the close relationship between destination and place branding; (3) show that a place brand profits from more brand complexity (especially for residents), while we argue that destination branding and place branding in general should not be seen as separated entities.

\section{Literature review}

\subsection{Destination branding and residents as focus}

Destination branding is a well-established concept in both academia and practice (Park \& Petrick, 2006; Qu et al., 2011), defined as a marketing tool intended to communicate a destination's unique identity and distinguish it from other destinations (Cai, 2002). Other researchers have expanded this concept into a more comprehensive strategy for not only targeting tourists, but also attracting and retaining residents (Hanna \& Rowley, 2015) while by definition destination branding targets solely tourists and place branding describes the general branding of places for all target groups (Kerr, 2006; Zenker \& Braun, 2010).

However, it is not surprising that residents play an important role in the tourism business and that the borders of both concepts are becoming 'blurred': Residents constitute an important part of the place and, by extension, visitors' experiences (Freire, 2009). They directly benefit from positive developments, as well as perceive the negative social and environmental effects of tourism (Sharpley, 2014). When residents are satisfied, they can function as place ambassadors (Palmer et al., 2013). Braun et al. (2013) also highlight the role of citizens in the legitimization of place planning and development in general. However, tourism research has devoted considerably more attention to residents' attitudes towards tourists (as individuals) and tourism planning (Sharpley, 2014; Wang \& Xu, 2015) than their perceptions of a place and how those might affect touristic goals.

Granted, there have been a few notable attempts at exploring this issue: Zenker \& Beckmann (2012) showed that residents and tourists harbour different perceptions of a place. Later, Palmer et al. (2013) focused on residents' personal identity and identification with the place, and the influence of such identification on advocacy. Recently, Hanna and Rowley (2015) made a first conceptual attempt at developing a model for a more comprehensive strategy encompassing tourists and residents. These few studies make it generally clear that "residents (..) should be in the central interest of urban tourism planners and managers to ensure that residents are proud and satisfied with the city" (Wang \& Xu, 2015, p. 248). A more complete understanding of residents' perceptions would thus be useful for tourism practice (Sharpley, 2014), not to mention relevant to the wider context of place marketing, where place identification (Zenker \& Petersen, 2014), place attachment (Altman \& Low, 1992; Lewicka, 2011) and place satisfaction (Fleury-Bahi, Félonneau, \& Marchand, 2008) are popular concepts.

As it stands, the need to research place brands for all different target groups and uncover potential synergies is slowly entering into the field's priorities (Hanna \& Rowley, 2015; Zenker \& Braun, 2010; Zenker \& Beckmann, 2012). However, it is also becoming apparent that the disciplinary demarcation between tourism and place marketing seems outdated, as a joined approach (either adding the target group of (potential) residents to the tourism brand or incorporating the tourism organization into greater place marketing units) is already quite common in practice. Nevertheless, to make a clear distinction for this article, we keep the definition of destination branding as an activity that solely targets tourists, while place branding includes all activities that target all potential place target groups (making destination branding a component of place branding).

\subsection{Place marketing}

Place branding (and by this destination branding) is located in the broader field of place marketing. In this regard, we understand place marketing as "the coordinated use of marketing tools supported by a shared customer-oriented philosophy, for creating, communicating, delivering, and exchanging urban 
offerings that have value for the city's customers and the city's community at large" (Braun, 2008, p. 43), which entails that place branding is one such marketing tool. Ashworth and Voogd (1990) argue that the objective of place marketing is to contribute to the efficient economic and social functioning of a place consistent with the wider goals have been established for the place. The insights of the authors cited above lead to two very important arguments: First, although an economic intention is included in place marketing, it also centrally aims to increase the social functions, like identification or satisfaction. Second, a customer-focused approach is key to place marketing, which should be based on the needs of all a place's customers. Of course, it is a considerable challenge for place marketers to address the needs of all potential customers (e.g., residents of different socioeconomic groups, subcultures, political orientations, and visitors). The first step in this process is to create a shared mental representation of the place-what marketers call the place brand. Kavaratzis (2004) contends that these mental representations are shaped by three types of place brand communication: (1) primary communication, including geographical location, architecture and infrastructure (e.g., socalled flagship buildings), as well as the place's behaviour (e.g., the behaviour of the inhabitants) and therefore could be labelled as 'place physics'; (2) the secondary communication, we would call the 'place communication', which is the communication through official channels like all forms of advertising, branding, or public relations; (3) the tertiary communication, which refers to the word-of-mouth reinforced by media and foremost by the residents themselves, and therefore could be labelled as 'place word-of-mouth.'

\subsection{Place brands}

Research has shown that place brands (including destination brands) are multidimensional (Kaplan, Yurt, Guneri, \& Kurtulus, 2010; Zenker, 2011). These brands comprise a large variety of variables, such as a place's buildings, history, economical and geographical aspects, and demographic characteristics. In addition to these basic associations, place brands also include associations attributed to these variables that are more evaluative such as modern, successful, old fashioned or central. All these variables are stored as associations in consumers' minds. While many definitions for place brands are in use, here the definition by Zenker and Braun (2010) is in focus, which refers to Keller's (1993) concept of brand knowledge. The authors define a place brand as "a network of associations in the place consumers' mind based on the visual, verbal, and behavioural expression of a place, which is embodied through the aims, communication, values, and the general culture of the place's stakeholders and the overall place design" (Zenker \& Braun, 2010, p. 4).

This definition again highlights the special role of residents in the place branding process - not only as a target group, but also as part of the place. Through (positive) word-of-mouth communication, residents become place ambassadors, in addition to being voters and citizens who initiate and legitimate place branding activities (Braun et al., 2013). Thus, residents play a central role in the branding process, and their identification with their place of living can be regarded as both an aim and facilitator of place branding (including destination branding).

\subsection{Research hypotheses}

\subsubsection{Identification and complexity}

One important facilitator of residential support in place marketing is residents' identification with the place (Palmer et al., 2013; Zenker \& Petersen, 2014). A number of goals can be served through identification. Social Identity Theory (Brewer, 1991; Hogg \& Abrams, 1988; Tajfel \& Turner, 1986) postulates that when individuals identify with social categories, they can bolster their self-perception by incorporating positive characteristics of said social category within the self-concept. By offering a positive self-image alongside implicit and explicit rules connected with group membership, identification can reduce uncertainty and facilitate decision-making (Hogg, 2000), as well as offer a sense of meaning and belonging (Baumeister \& Leary, 1995). In its broadest sense, the concept of identification can be defined as creating a meaningful connection between the self and the target of identification (here: the place). This connection involves the incorporation of the attributes of the identification target (i.e., the place brand) into the self-concept. While the place brand's substance cannot be changed easily (Zenker, 2011), other characteristics can be modified: namely, the perceived complexity of the place brand.

Rapoport and Hawkes (1970, p. 108) defined complexity as "a set of elements involving relationships among them." Zenker and Petersen (2014, pp. 718-719) in contrast focus on complexity "as (a) a quantitative measure and (b) a construct with different qualities." Thus, it can be characterized by its 'quantity' (i.e., by how many different elements are included) and its 'qualities', involving 'ambiguity' (having for instance rich and poor residents at the same time) or the 'degrees of entropy' (level of how organized the complexity is).

Because branding is often understood as a process of reduction and concentration on core associations (Anholt, 2009; Keller, 2003), practitioners and researchers alike tend to react negatively to complexity. Complexity may be regarded as an unclear brand concept, meaning that the brand is fuzzy, elusive or incoherently positioned in comparison to other brands. In addition, marketers fear that consumers will become overloaded by having to sort through and evaluate complex information. For instance, Bettman, Frances, and Payne (1998) suggested that in cases of high product complexity, customers apply simpler heuristics and selective information processing, even though this reduces the effectiveness of their decisions. Likewise, Swaminathan (2003) showed that in cases of high complexity, recommendations have a stronger impact on consumers. Research on task complexity highlights that consumers use different strategies to filter information that is important for their decision (Lussier \& Olshavsky, 1979). When the brand itself is simple, consumers with little information at hand can more accurately identify the brand, but they may also show more dissatisfaction with the brand and a higher need for more information (Scammon, 1977). In addition, it appears that advertisements that are more complex receive results that are more positive: Research has found that complex advertisements are evaluated more positively and receive a higher number of exposures than simpler advertisements (Cox \& Cox, 1988; Janiszewski \& Meyvis, 2001). Since a place to live is highly important for nearly every aspect of life, we propose that individuals are willing to invest effort in information-seeking and processing. A higher perceived complexity of a place brand can facilitate place identification (and other place attitudes, like satisfaction and attachment) by having an effect on the attractiveness of identification, identity fit, and optimal distinctiveness that are the determinants of identification (Tajfel \& Turner, 1986).

\subsubsection{Attractiveness of identification}

Attractiveness of identification can be seen as the level of how 
appealing a proposed identity is to increase the self-definition of the identity holder in positive terms (Hogg \& Abrams, 1988; Tajfel \& Turner, 1986). For instance, it becomes much more attractive to identify with a place that can bolster a very positive place brand as it encourages individuals to adopt the city's positive aspects into their self-concept, thereby enhancing selfesteem. However, few places thrive on positive attributes alone. Barcelona, for example, is known as one of the most attractive cities in Europe, but at the same time it is also perceived as overcrowded and a pickpocket's paradise. When the perceived complexity is at a high level, it could buffer against the influence of negative city characteristics through compartmentalization (Showers, 1992). This process of compartmentalization encompasses the extent to which knowledge about a stimulus-both positive and negative-is disentangled into separate categories, sorting out negative aspects into categories that are less central. The so-called spill-over effects, that is a negative event concerning one aspect taints an identity as a whole (Linville, 1985, 1987; Rafaeli-Mor \& Steinberg, 2002), can be reduced when the overlap between aspects of an identity is perceived to be low. In addition, a low perceived overlap might help to buffer against extreme evaluations of the general place brand. For example, if a place is considered to be unsafe this should have a stronger negative effect on the place brand when the perceived place brand complexity is low. On the other hand, when a place brand is more complex, other characteristics of the place could overshadow this negative characteristic and people allow more complexity in their evaluation, understanding that most places have both safe and unsafe neighbourhoods. Thus, we assume that brand complexity positively influence the attractiveness of identification, which is a determinant of identification-or in other words:

H1a. A higher perceived city brand complexity increases identification mediated by attractiveness of identification.

\subsubsection{Identity fit}

For place identification to occur, a certain degree of identity fit is necessary. Fit can be defined as the level of congruence between the persons' identity and the evaluated identity (Hogg \& Abrams, 1988; Tajfel \& Turner, 1986). Person-environment (P-E) fit models (Phillips, Cheng, Yeh, \& Sui, 2010) propose that perceived identity fit relates to parallels in core-attributes and values between the place and the self. In addition, Sirgy, Grzeskowiak, and Su (2005) argue that the image of people living in a place can also have an effect on housing choice. A higher match between the self-concept and the residential occupant image of a home and neighbourhood makes that place more attractive. Sirgy et al. (2005, p. 333) distinguish the actual self-image ("defined as how consumers see themselves") and the ideal self-image ("defined as how consumers would like to see themselves"). Creating a high brand complexity could possibly increase perceived fit in both categories. For example, if a place markets itself as 'young and creative', without paying attention to the existing variety of place inhabitants and place visitors, the identity fit applies exclusively to a very narrow target audience (i.e., the young and creative; Zenker, Gollan, \& Van Quaquebeke, 2014). Even though inhabitants and visitors could feel attracted to this young and creative profile (ideal self-image), the majority of them will not have these characteristics in their self-concept (actual self-image) thus being unable to identify with the place brand. When the perceived level of place brand complexity is higher, the dissonance between a person's attributes and values and those of the place is reduced. In this way, it is more likely to connect the place to the self in a meaningful way, thus:

H1b. A higher perceived city brand complexity increases identification mediated by identity fit.

\subsubsection{Optimal distinctiveness}

While identification is facilitated by identity fit, it is argued that a complete match is not desirable. Next to the people's need to belong (Baumeister \& Leary, 1995), there is the need to stay unique and recognizable as an individual (Brewer, 1991, 2003; Sheldon \& Bettencourt, 2002). This is related to a certain need for personal individualism, as an "emphasis on personal autonomy and selffulfillment, and the basing of one's identity on one's personal accomplishments" (Oyserman, Coon, \& Kemmelmeier, 2002, p. 4). Hence, people search for an optimal balance between adopting the place's core-attributes and being recognised as unique individuals-so called optimal distinctiveness. This concept can be defined as the level of freedom to stay different, while still being part of the group identity (Hogg \& Abrams, 1988; Tajfel \& Turner, 1986). Accepting place brand complexity allows for smaller-scale subcategories to be integrated into the larger mental representation of a place, which helps individuals to feel important and relevant without feeling individuated or isolated (Abrams, 2009). These optimal, distinct subgroups within a mental representation of a place grant a stronger identification than monolithic representations (Abrams, 2009). Therefore, higher brand complexity should allow for more perceived optimal distinctiveness. While arguing that complexity lead to a higher identity-fit (H1b) and optimal distinctiveness (H1c) at the same time may sound like a paradox, it is not. People are selective in finding similarities (e.g., age, gender, or social-status) while they still recognise other differences to fulfil their need of staying recognizable as an individual (Brewer, 1991, 2003). Thus, we hypothesize:

H1c. A higher perceived city brand complexity increases identification mediated by optimal distinctiveness.

\subsubsection{Place attachment and commitment}

Besides being related to place identification, all these concepts mentioned above are strongly associated with other important place attitudes, namely place attachment or commitment. Place attachment is a popular concept in place related studies (Altman \& Low, 1992; Knez, 2005; Lewicka, 2011). In general it can be defined as, a measure of "emotional bonds which people develop with various places” (Lewicka, 2011, p. 219). For residents, higher identification with their place of living likely reflects a strong place attachment (Zenker \& Petersen, 2014). For external target groups, like tourists, some form of place attachment can also increase with a higher level of involvement with said place (Gross \& Brown, 2006). However, it must be stated that this attachment may not be of the same type or level of attachment in comparison with residents.

A similar concept from social psychology is the concept of commitment (Zenker \& Petersen, 2014). Commitment describes 'psychological ownership' (Zenker \& Petersen, 2014), where a committed place user will form a meaningful link between the selfconcept and the place-therefore we use the two concepts interchangeably here. In sum, we hypothesize:

H2a. Identification with a place is positively related to place attachment/commitment. 


\subsubsection{Place satisfaction}

Following Ashworth and Voogd (1990) definition of place marketing, it is a goal in itself of marketing to increase satisfaction with the place for all place users. Higher identification with a place will also increase place satisfaction (Fleury-Bahi et al., 2008): People evaluate the city much more positively as the city becomes part of the self (serving a positive self-concept) and therefore will be more satisfied with a place's offerings (Insch \& Florek, 2010; Zenker, Petersen, \& Aholt, 2013). Thus, we hypothesize:

H2b. Identification with a place is positively related to place satisfaction.

\subsubsection{Indicator of positive place behaviour}

In the research domain of identification with employers, Bergami and Bagozzi (2000) have found a powerful relationship between members' loyalty to the organization, satisfaction and identification. Similarly, scholars have found that identification with a brand community leads to higher brand loyalty (Stokburger-Sauer, 2010), as does consumer-brand identification (Stokburger-Sauer, Ratneshwar, \& Sen, 2012). Thus, attachment, satisfaction, and identification are supposed to increase the exhibition of positive citizenship behaviour (Stedman, 2002), such as positive word-of-mouth about a place. Carroll and Ahuvia (2006), for instance, showed that a positive brand evaluation leads to higher brand loyalty and positive brand behaviour like positive word-of-mouth. Additionally, Stokburger-Sauer et al. (2012) uncovered that consumer-brand identification leads to brand advocacy, both physically (e.g., wearing clothing with the brand logo) and socially (i.e., positive word-of-mouth). Finally, Palmer et al. (2013) found a positive relationship between identification with the place and advocacy of incoming tourism. Thus, with taking positive word-of-mouth as indicator of positive place behaviour, we hypothesize:

H3a. Place identification increases positive word-of-mouth.

H3b. Place attachment/commitment increases positive word-ofmouth.

H3c. Place satisfaction increases positive word-of-mouth.

\subsubsection{Differences between residents and visitors}

As elaborated before, the effectiveness of simplified branding (reducing the brand to a limited number of core messages) in the context of complex place brands is questionable. While many places try to focus on communicating their place as unique and iconic, they constantly try to reduce the real complexity of a place (Anholt, 2009; Kavaratzis \& Ashworth, 2007). However, especially internal target audiences and heavy place users possess a confounded knowledge of the branded object and could disagree with the simplified brand message (Zenker \& Beckmann, 2012). Those users perceive places as the complex object they are regarding the quantity of complexity (number of different elements), ambiguity (e.g., rich and poor at the same time), or the degrees of entropy (level of how organized the complexity is). Thus, a simplified brand message should result in lower brand identification and less favourable behaviour (Zenker \& Petersen, 2014) in the case of residents in comparison to visitors (non-residents). This does not mean that brand complexity could not have in general a positive effect on all target audiences: For example, Lowrey (1998) shows that advertisement persuasiveness is positively affected by syntactic complexity of the ad. Likewise, Pieters,
Wedel, and Batra (2010) show that the design complexity of advertisement increases attention and attitude towards an ad. However, we assume this effect to be much stronger for residents, since they are not only brand ambassadors but also part of the place brand (Braun et al., 2013). Like employees in an organization, there is a stronger relationship to the organizational brand than for customers, since they are 'living the brand'. For instance in hospitality organizations, the brand knowledge of employees contributes to their probrand behaviour, if employees see the brand as relevant and foremost meaningful (Xiong, King, \& Piehler, 2013). A higher brand complexity could be helpful in this regards. In addition, a study on citizen brand ambassadors' motivation shows that most of the active brand ambassadors of the Berlin brand are driven by their personal interest in enhancing the reach and exposure of their individual projects (Rehmet \& Dinnie, 2013). A more complex brand is more likely to include aspects that are of relevance for these internal stakeholders while it shows less relevance for external target audiences. Consequently, the relationship of brand complexity on identification, attachment, and satisfaction should be influenced by the characteristic of the place user (i.e., between residents and non-residents):

H4a. A higher perceived city brand complexity increases identification for residents more than for non-residents.

H4b. A higher perceived city brand complexity increases attachment/commitment for residents more than for non-residents.

H4c. A higher perceived city brand complexity increases satisfaction for residents more than for non-residents.

\section{Empirical studies}

\subsection{Sample and method (study 1)}

The study was conducted in Germany as an online survey in cooperation with the research panel of the EuroFH University. The survey's participants were working and studying at the same time in a distance-learning program (adult-education). Of the 768 participants, three participants disagreed to the use of their data for scientific analysis (direct control question) and/or failed the control question intended to assess careful reading of the survey ("please choose here the middle of the scale"), and thus were excluded from the calculations. The mean age of the remaining 765 participants (50\% women) was 31.77 years $(S D=7.82)$; 55 percent had a high school degree and one third (31\%) had a university degree. Their average number of years in their current place of living was 14.33 ( $S D=12.23$ ). Of course, the sample cannot be seen as representative for the German population-however, as so-called (future) talents they are an important and relevant target group for places (Zenker and Braun, 2010; Zenker \& Beckmann, 2012).

The survey measured the following constructs: brand complexity (adopted from Cox \& Cox, 1988), identity-fit (Brown \& Rafaeli, 2007), attractiveness of identification (Osgood, Suci, \& Tannenbaum, 1957), optimal distinctiveness and identification (Bhattacharya \& Sen, 2003), satisfaction (Zenker et al., 2013), attachment (Zenker \& Gollan, 2010), and positive word-of-mouth (Carroll \& Ahuvia, 2006) - see appendix for all used items. All items were measured with a 7-point Likert scale ranging from 1 ("I fully disagree") to 7 ("I fully agree") with one exception: identity-fit was measured using a VENN-diagram. The end of the survey asked for common demographic attributes like age, gender, and educational background. Additionally, in the survey, all items were randomized and some of 
Table 1

Pearson correlation matrix with Cronbach's $\alpha$, means and standard deviations for all scales (study 1 ).

\begin{tabular}{|c|c|c|c|c|c|c|c|c|c|c|}
\hline Variables & 1 & 2 & 3 & 4 & 5 & 6 & 7 & 8 & $M$ & $S D$ \\
\hline 1. Brand Complexity & $(0.87)$ & & & & & & & & 4.47 & 1.54 \\
\hline 2. ID-Fit $^{\mathrm{a}}$ & 0.41 & - & & & & & & & 5.00 & 1.41 \\
\hline 3. Distinctiveness & 0.55 & 0.40 & $(0.89)$ & & & & & & 4.68 & 1.66 \\
\hline 4. Attractiveness of ID & 0.48 & 0.69 & 0.48 & $(0.94)$ & & & & & 5.32 & 1.43 \\
\hline 5. Identification & 0.32 & 0.38 & 0.34 & 0.39 & $(0.87)$ & & & & 3.19 & 1.57 \\
\hline 6. Attachment & 0.32 & 0.61 & 0.40 & 0.62 & 0.50 & $(0.83)$ & & & 4.16 & 1.69 \\
\hline 7. Satisfaction & 0.35 & 0.68 & 0.38 & 0.79 & 0.39 & 0.70 & $(0.94)$ & & 5.60 & 1.49 \\
\hline 8. Word-of-Mouth & 0.37 & 0.44 & 0.44 & 0.50 & 0.60 & 0.50 & 0.49 & $(0.91)$ & 3.69 & 1.67 \\
\hline
\end{tabular}

Note: $N=765$; Cronbach's $\alpha$ shown in brackets.

All correlations are significant at $\mathrm{p}<0.001$.

a One-Item-Scale (Venn-diagram).

them were reversed coded, to increase reliability and validity. We further assessed whether common method bias is a problem in study 1 by loading all items upon one common factor in a confirmatory factor analysis framework, as this is more sophisticated than the traditional Harman's single factor test using explorative factor analysis (Podsakoff, MacKenzie, Lee \& Podsakoff, 2003). For study 1, the model with one single factor for all items did not fit the data very well $(\mathrm{CMIN} / \mathrm{DF}=22.98 ; \mathrm{RSMEA}=0.18: \mathrm{CFI}=0.59$; $\mathrm{TLI}=0.55$; PCLOSE $=0.00$; SRMS $=0.12 ; \mathrm{R}^{2}=0.96$ ). These fit indices indicates that common method bias does not seem to be a problem.

\subsection{Results (study 1)}

The correlations between all variables, the means, standard deviations, and Cronbach's $\alpha$ are shown in Table 1. The data analysis in study 1 took the form of structural equation modelling (SEM). The structural equation model is estimated with the Satorra-Bentler correction (Satorra \& Bentler, 1994). This estimation method produces the Satorra-Bentler scaled $\chi 2$ and makes standard errors, $p$-values, confidence intervals, and the analysis of effects robust to data non-normality. In addition, the structural model is also estimated by using 5000 bootstrap

Table 2

Standardized factor loadings, Composite Reliability, Average Variance Extracted (study 1 ).

\begin{tabular}{lllll}
\hline Construct & Item label & $\beta$ & CR & AVE \\
\hline Brand Complexity & BC1 & 0.71 & 0.87 & 0.70 \\
& BC2 & 0.95 & & \\
Attractiveness of Identification & BC3 & 0.83 & & \\
& AI1 & 0.93 & 0.94 & 0.84 \\
& AI2 & 0.87 & & \\
Optimal Distinctiveness & AI3 & 0.94 & & \\
& OD1 & 0.91 & 0.89 & 0.74 \\
& OD2 & 0.88 & & \\
Identification & OD3 & 0.78 & & \\
& ID1 & 0.77 & 0.87 & 0.63 \\
& ID2 & 0.75 & & \\
Satisfaction & ID3 & 0.79 & & \\
& ID4 & 0.86 & & \multirow{5}{*}{ SA1 } \\
Attachment & SA2 & 0.92 & 0.94 & 0.84 \\
& SA3 & 0.85 & & \\
Word-of-Mouth & AT1 & 0.77 & 0.84 & 0.63 \\
& AT2 & 0.86 & & \\
& AT3 & 0.75 & & \\
& WM1 & 0.86 & 0.93 & 0.76 \\
& WM2 & 0.91 & & \\
& WM3 & 0.82 & & \\
\hline
\end{tabular}

Note: The factor scores come from the CFA-model and CR and AVE have been calculated with these scores. The item labels correspond to the table listing the items in the Annex. replicates by re-sampling. The results of both procedures are highly similar.

To take a closer look at the measurement model, Campbell and Fiske (1959) proposed to test construct validity by testing convergent and discriminant validity. Table 2 presents the factor loadings $(\beta)$, composite reliability (CR) and the average variance extracted (AVE). Cronbach's $\alpha$ were already reported in Table 1.

All items loaded significantly ( $\mathrm{p}<0.001$ ) on to the constructs and all factor loadings are higher than 0.71 . The values of Cronbach's $\alpha$ and CR are all higher than 0.80 and AVE ranged from 0.63 to 0.84 . Hence, the internal consistency of the constructs and convergent validity is evidenced (Fornell \& Larcker, 1981). Next, two methods are used to test for discriminant validity. First, following Fornell and Larcker (1981), discriminant validity for each construct is established when the construct's AVE is higher than the shared variance with the other constructs in the model (i.e., the squared correlations). The upper part of Table 3 shows that this is the case for each construct in the model.

Second, we apply a relatively new criterion for assessing discriminant validity based on developed by Henseler, Ringle, and Sarstedt (2015): the heterotrait-monotrait (HTMT) ratio of correlations. It is calculated as "the average of the heterotraitheteromethod correlations relative to the average of the monotrait-heteromethod correlations" (Henseler et al., 2015, p. 121). To demonstrate discriminant validity, the HTMT ratio of correlations should be lower than 0.85 (Kline, 2011) or 0.90 (Teo,

Table 3

Discriminant validity of the latent variables (study 1 ).

\begin{tabular}{lllllllll}
\hline & AVE and SC & 1 & 2 & 3 & 4 & 5 & 6 & 7 \\
\hline 1 & Complexity & $\mathbf{0 . 7 0}$ & 0.38 & 0.29 & 0.13 & 0.14 & 0.16 & 0.18 \\
2 & Distinctiveness & 0.62 & $\mathbf{0 . 7 4}$ & 0.27 & 0.15 & 0.22 & 0.18 & 0.24 \\
3 & Attractiveness of ID & 0.54 & 0.52 & $\mathbf{0 . 8 4}$ & 0.19 & 0.50 & 0.69 & 0.29 \\
4 & Identification & 0.36 & 0.39 & 0.44 & $\mathbf{0 . 6 3}$ & 0.34 & 0.20 & 0.45 \\
5 & Attachment & 0.38 & 0.47 & 0.71 & 0.58 & $\mathbf{0 . 6 3}$ & 0.62 & 0.32 \\
6 & Satisfaction & 0.40 & 0.43 & 0.83 & 0.45 & 0.79 & $\mathbf{0 . 8 4}$ & 0.28 \\
7 & Word-of-Mouth & 0.42 & 0.49 & 0.54 & 0.67 & 0.57 & 0.53 & $\mathbf{0 . 7 6}$ \\
\hline & HTMT ratio & $\mathbf{1}$ & $\mathbf{2}$ & $\mathbf{3}$ & $\mathbf{4}$ & $\mathbf{5}$ & - & - \\
\hline 1 & Complexity & - & & & & & & \\
2 & Distinctiveness & 0.63 & - & & & & & \\
3 & Attractiveness of ID & 0.54 & 0.52 & - & & & & \\
4 & Identification & 0.36 & 0.39 & 0.43 & - & & & \\
5 & Attachment & 0.37 & 0.46 & 0.71 & 0.59 & - & & \\
6 & Satisfaction & 0.38 & 0.41 & 0.84 & 0.44 & 0.68 & - & \\
7 & Word-of-Mouth & 0.45 & 0.51 & 0.57 & 0.67 & 0.51 & 0.55 & - \\
\hline
\end{tabular}

Note: The upper part of the table concerns the Fornell and Larker criterion, the lower part the HTMT-ratio's. In the upper part of the table, the correlations are below the diagonal, squared correlations (SC) are above the diagonal in italics, and AVE estimates are presented on the diagonal in bold. The correlations come from the CFAmodel and these have been corrected for attenuation due to measurement error. All correlations are significant at $\mathrm{p}<0.001$. 


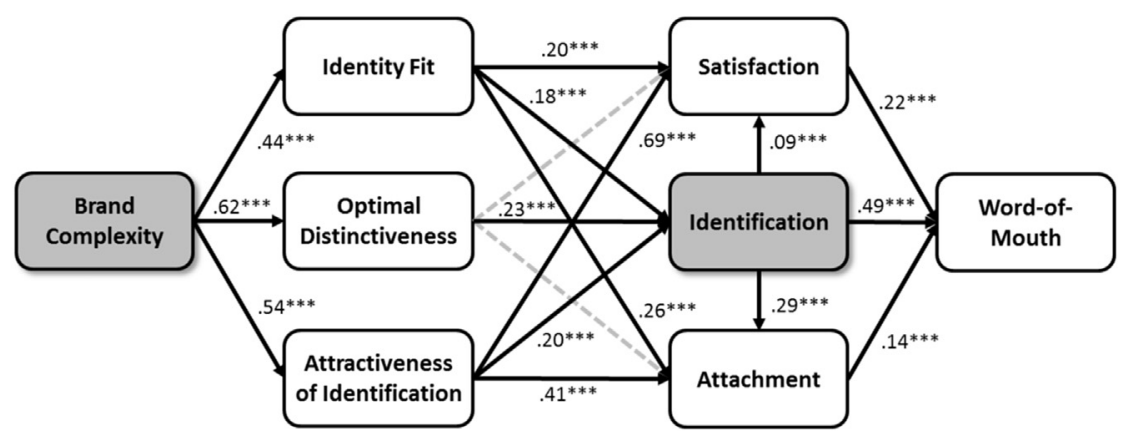

Fig. 1. SEM model study 1 (standardized regression coefficients).

Srivastava, \& Jiang, 2008). Voorhees, Brady, Calantone, and Ramirez (2016) showed that the cut-off value of 0.85 for the HTMT ratio performed very well in covariance based SEM. The HTMT ratios are reported in the lower part of Table 3 and all ratios are below the most conservative cut-off value of 0.85 . Discriminant validity has been established by both methods.

The SEM model with the standardized regression coefficients is shown in Fig. 1. The overall fit for this model is good (Hu \& Bentler, 1999): The CMIN/DF $=2.37$ is lower than the benchmark of 5 (Arbuckle \& Wothke, 1999); the RMSEA of 0.04 is below the cut-off value of 0.06 for large samples and PCLOSE $=0.90$; the SRMR of 0.04 is much lower than the threshold of 0.08 and finally, the TLI of 0.97 and the CFI of 0.97 are higher than the benchmark of 0.95 ( Hu \& Bentler, 1999).

The results show that brand complexity positively influenced identification, mediated by the determinants of identification, namely identity fit, attractiveness of identification and optimal distinctiveness (H1a-c). Two constructs worked positively on all attitude measurements (i.e., satisfaction, attachment, and identification), while optimal distinctiveness is only positively related to identification. Identification-as the key element of our model-is positively influencing satisfaction and attachment (supporting our hypotheses $\mathrm{H} 2 \mathrm{a}$ and $\mathrm{H} 2 \mathrm{~b}$ ). Furthermore, does identification demonstrated an especially important influence on the measurement of word-of-mouth (H3a). Attachment and satisfaction both also positively affect word-of-mouth (H3b and $\mathrm{H} 3 \mathrm{c}$ ). The R-square for the overall model is 92.6 percent.

\subsection{Sample and method (study 2)}

Since the aim of the second study was to test the impact of brand complexity for residents and tourists $(\mathrm{H} 4 \mathrm{a}-\mathrm{c})$, we conducted the study in cooperation with a provisional panel provider (Respondi AG); participants included 200 residents of the city of Hamburg
(Germany) and 200 non-residents (Germans not living and never lived in Hamburg, regarded as potential domestic tourists). In line with the first study, we excluded those cases where participants disagreed to the use of their data for scientific analysis and/or failed at the control question for careful reading (15 participants). Thus, 385 participants (191 residents of Hamburg and 194 non-residents) remained. Again, half (50.1\%) of the participants were female, while the mean age was 47.46 years $(S D=14.31)$ and 35.3 percent had a university degree. The resident group's mean living experience in the city of Hamburg was 31.75 years $(S D=20.63)$. Again, this sample cannot be seen as representative for the German population.

As in the first study, we measured brand complexity, satisfaction, identification and word-of-mouth. Additionally, we operationalized attachment to a place with a commitment scale adopted from Allen and Meyer (1990), since the attachment measure used in study 1 focused too strongly on current residents. Similarly to study 1 , we assessed whether common method bias is a problem in study 2 by loading all items upon one common factor in a confirmatory factor analysis framework. The one factor CFAmodel for study 2 has bad goodness of fit statistics (CMIN/ $\mathrm{DF}=15.35 ; \mathrm{RSMEA}=0.19 ; \mathrm{CFI}=0.71 ; \mathrm{TLI}=0.67 ; \mathrm{PCLOSE}=0.00$; $\mathrm{SRMR}=0.11 \mathrm{R}^{2}=0.96$ ) and this indicates that common method bias does not seem to be a problem.

\subsection{Results (study 2)}

Table 4 shows the correlations between all variables, the means, standard deviations, and Cronbach's $\alpha$. The model was tested as a moderated multiple mediation model (Hayes \& Preacher, 2012) using regression analysis and the PROCESS tool by Hayes (2013). As Hayes (2013, p. 402) state, moderated mediation is present, "if the indirect effect of $\mathrm{X}$ on $\mathrm{Y}$ through $\mathrm{M}_{\mathrm{j}}$ depends on a particular moderator" (where $\mathrm{X}$ is the independent and $\mathrm{Y}$ the dependent

Table 4

Pearson correlation matrix with Cronbach's $\alpha$, means and standard deviations for all scales (study 2).

\begin{tabular}{|c|c|c|c|c|c|c|c|c|}
\hline Variables & 1 & 2 & 3 & 4 & 5 & 6 & $M$ & $S D$ \\
\hline 1. Resident/non-resident ${ }^{\mathrm{a}}$ & - & & & & & & 0.50 & 0.50 \\
\hline 2. Brand Complexity & $-0.12^{*}$ & $(0.85)$ & & & & & 5.93 & 1.12 \\
\hline 3. Identification & $-64^{* * *}$ & $0.19^{* * *}$ & $(0.93)$ & & & & 3.18 & 1.76 \\
\hline 4. Satisfaction & $-0.53^{* * *}$ & $0.38^{* * *}$ & $0.63^{* * *}$ & $(0.85)$ & & & 5.44 & 1.49 \\
\hline 5. Commitment & $-0.67^{* * *}$ & $0.31^{* * *}$ & $0.72^{* * *}$ & $0.73^{* * * *}$ & $(0.88)$ & & 4.19 & 2.06 \\
\hline 6. Word-of-Mouth & $-0.56^{* * *}$ & $0.26^{* * *}$ & $0.76^{* * *}$ & $0.72^{* * *}$ & $0.74^{* * *}$ & $(0.96)$ & 3.87 & 1.98 \\
\hline
\end{tabular}

Note: $N=385$; Cronbach's $\alpha$ shown in brackets.

${ }^{*} p<0.05 ;{ }^{* *} \mathrm{p}<0.01 ;{ }^{* * *} \mathrm{p}<0.001$.

a Dichotomous item $(0=$ non-resident, $1=$ resident $)$. 
Table 5

Standardized factor loadings, composite reliability, average variance extracted (study 2).

\begin{tabular}{lllll}
\hline Construct & Item label & $\beta$ & CR & AVE \\
\hline Brand Complexity & BC1 & 0.62 & 0.87 & 0.70 \\
& BC2 & 0.98 & & \\
Identification & BC3 & 0.87 & & \\
& ID1 & 0.87 & 0.93 & 0.77 \\
& ID2 & 0.81 & & \\
ID3 & 0.88 & & \\
Satisfaction & ID4 & 0.93 & & 0.68 \\
& SA1 & 0.87 & 0.86 & \\
Word-of-Mouth & SA2 & 0.92 & & 0.86 \\
& SA3 & 0.66 & & \\
& WM1 & 0.92 & 0.96 & \\
& WM2 & 0.96 & & 0.74 \\
Commitment & WM3 & 0.91 & & \\
& WM4 & 0.92 & & \\
& CT1 & 0.81 & 0.87 & \\
& CT2 & 0.83 & & \\
& CT3 & 0.84 & & \\
\hline
\end{tabular}

Note: The factor scores come from the CFA-model and CR and AVE have been calculated with these scores. The item labels correspond to the table listing the items in the Annex.

Table 6

Discriminant validity of the latent variables in study 2 .

\begin{tabular}{lllllll}
\hline & AVE and SC & 1 & 2 & 3 & 4 & 5 \\
\hline 1 & Complexity & $\mathbf{0 . 7 0}$ & 0.04 & 0.18 & 0.09 & 0.12 \\
2 & Identification & 0.20 & $\mathbf{0 . 7 7}$ & 0.51 & 0.63 & 0.67 \\
3 & Satisfaction & 0.42 & 0.71 & $\mathbf{0 . 6 8}$ & 0.63 & 0.65 \\
4 & Word-of-Mouth & 0.30 & 0.79 & 0.79 & $\mathbf{0 . 8 6}$ & 0.59 \\
5 & Commitment & 0.34 & 0.82 & 0.81 & 0.77 & $\mathbf{0 . 7 4}$ \\
\hline & HTMT ratio & $\mathbf{1}$ & $\mathbf{2}$ & $\mathbf{3}$ & $\mathbf{4}$ & $\mathbf{5}$ \\
\hline 1 & Complexity & - & & & & \\
2 & Identification & 0.21 & - & & & \\
3 & Satisfaction & 0.46 & 0.74 & - & & \\
4 & Word-of-Mouth & 0.31 & 0.86 & 0.46 & - & \\
5 & Commitment & 0.35 & 0.80 & 0.86 & 0.83 & - \\
\hline
\end{tabular}

Note: The upper part of the table concerns the Fornell and Larker criterion, the lower part the HTMT-ratio's. In the upper part of the table, the correlations are below the diagonal, squared correlations (SC) are above the diagonal in italics, and AVE estimates are presented on the diagonal in bold. The correlations come from the CFAmodel and these have been corrected for attenuation due to measurement error. All correlations are significant at $\mathrm{p}<0.001$. variable, while $\mathrm{M}_{\mathrm{j}}$ stands for the mediators). In doing so, first the (multiple-) mediation was tested-that is, if the relationship of X on $\mathrm{Y}$ is lowered (partial mediation) or even not significant anymore by adding the mediators $\mathrm{M}_{\mathrm{j}}$ (complete mediation). For testing the moderation effect, the interaction term of the independent variable $\mathrm{X}$ and the moderator (dummy variable $\mathrm{W}$ ) is used (Hayes \& Preacher, 2012). The models are estimated by using 1000 bootstrap replicates by re-sampling.

Before estimating the moderated multiple mediation model, we examined construct validity in a confirmatory factor analysis framework just as we have done for study 1 . Table 5 reports the factor loadings $(\beta)$, composite reliability (CR) and the average variance extracted (AVE) of the constructs used in study 2 .

All items load significantly ( $p<0.001$ ) on to the constructs and all factor loadings are higher than 0.62 . The values of Cronbach's $\alpha$ and CR are all higher than 0.80 and AVE range from 0.70 to 0.86 . Hence, the internal consistency of the constructs and convergent validity has been established.

Similarly to study 1 , two methods are used to test for discriminant validity. First, the construct's AVE is compared to the shared variance with the other constructs in the model (i.e., the squared correlations). The upper part of Table 6 reveals that AVE is higher than the shared variance with other constructs for each construct in the model as shown in the upper part of Table 6. Next, the heterotrait-monotrait (HTMT) ratio of correlations are calculated. Eight out of ten HTMT are below the most conservative threshold of 0.85 and two HTMT ratios are lower than the threshold of 0.90 . Discriminant validity has been established by both methods.

Before estimating the moderated mediation model, we first calculated a multiple mediation model (with PROCESS tool by Hayes (2013), version 2.15, model 4). As expected, under the mediation condition, the relationship (direct effect) between brand complexity $(\mathrm{X})$ and word-of-mouth $(\mathrm{Y})$ decreased and was no longer significant $(\beta=0.00, p=0.97)$ when estimated in a model with the three mediators that show a strong direct effect on wordof-mouth: satisfaction (M1: $\beta=0.32, p=0.00, C I_{95 \%}=0.23$ to 0.41 ), identification (M2: $\beta=0.41, p=0.00, C_{95 \%}=0.32$ to 0.50 ) and commitment (M3: $\beta=0.19, p=0.00, C_{95 \%}=0.09$ to 0.29 ). This can be seen as complete mediation according to Hayes (2013). Brand complexity was positively related to satisfaction $(\beta=0.38, p=0.00$, $C_{95 \%}=0.29$ to 0.47$)$, identification $\left(\beta=0.19, p=0.00, C_{95 \%}=0.09\right.$ to 0.28 ), and commitment ( $\beta=0.31, p=0.001, C I_{95 \%}=0.21$ to 0.40 ). This leads to an indirect effect of brand complexity on word-ofmouth through satisfaction $\left(\beta=0.12, C_{95 \%}=0.07\right.$ to 0.17 ), identification ( $\beta=0.08, C_{95 \%}=0.04$ to 0.13$)$ and commitment $(\beta=0.06$,

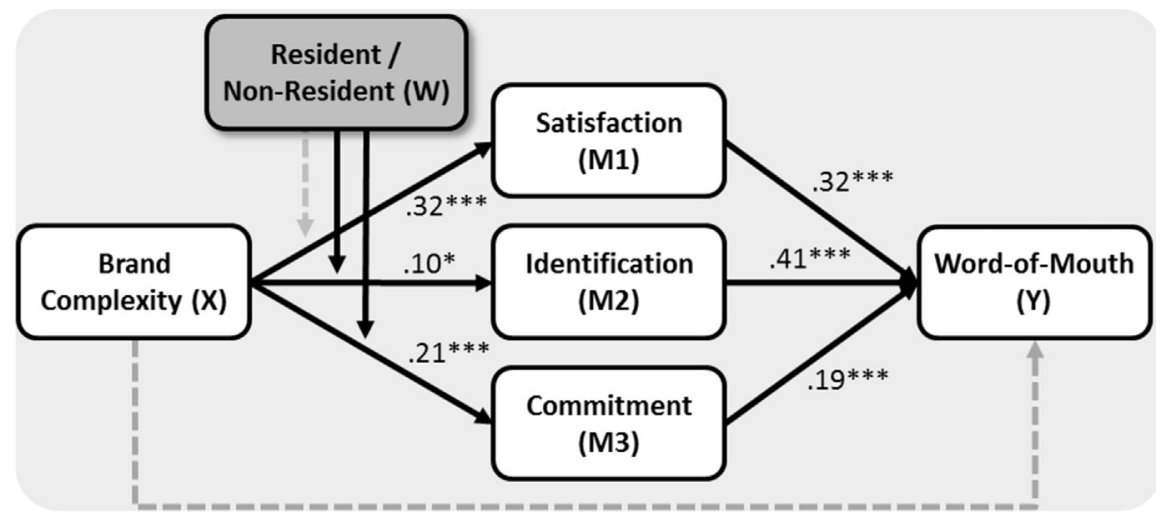

Fig. 2. Research model study 2 (including standardized regression coefficients for moderated multiple mediation model). 

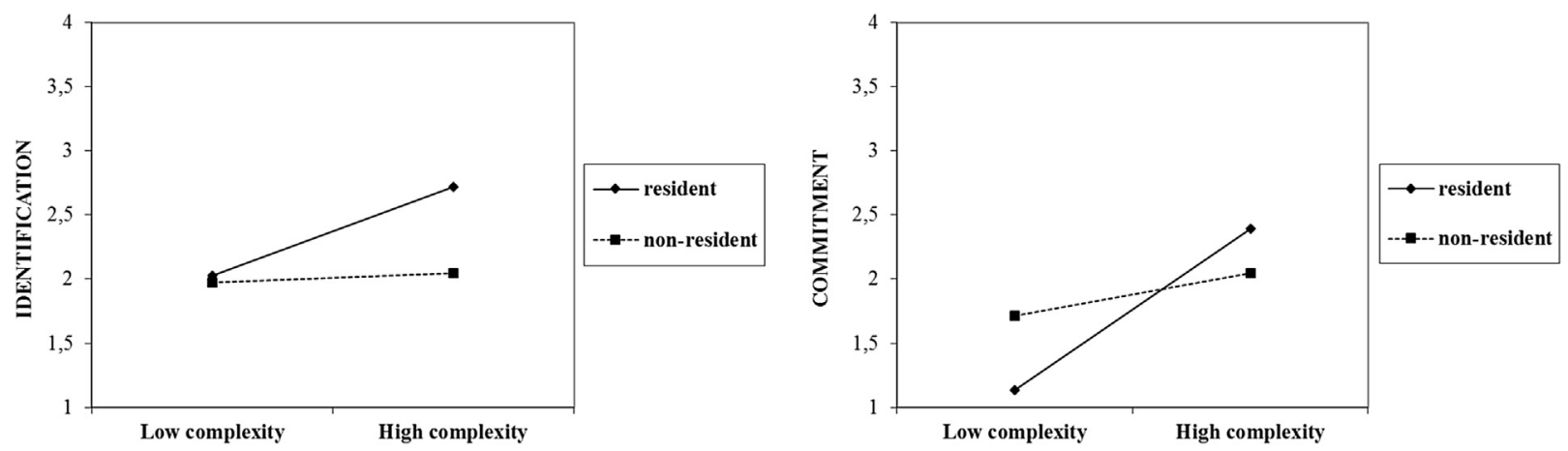

Fig. 3. Simple slopes study 2 (moderation).

$C I_{95 \%}=0.03$ to 0.11$)$ with CIs that do not include zero. The full mediation model explained 69 percent of the whole variance $\left(R^{2}=0.69, F(4,380)=208.86, p=0.00\right)$.

Next, a moderated multiple mediation model was estimated (with PROCESS tool by Hayes (2013), version 2.15, model 7) as shown in Fig. 2. In this model resident status is introduced as a moderator affecting the relationship between the brand complexity and the three mediators. It involves introducing resident status (dummy-coded $\mathrm{W}$ ) as well as an interaction term of brand complexity $(\mathrm{X})$ and resident status $(\mathrm{W})$ in the regression analysis. It is evidenced that the strength of the relationship between brand complexity and word-of-mouth (mediated by identification and commitment) was influenced by the resident status (see also simple slope figures for significant relationships in Fig. 3). First, the relationships between brand complexity and identification (interaction term: $\beta=-0.10, p=0.01, C_{95 \%}=-0.18$ to -0.02 ), and brand complexity and commitment (interaction term: $\beta=-0.13$, $p=0.001, C I_{95 \%}=-0.20$ to -0.06$)$ are affected by the residential status. Second, the PROCESS tool also reports the index of moderated mediation developed by Hayes (2015) for identification (index $=-0.08, C_{95 \%}=-0.17$ to -0.02 ) and commitment (index $=-0.05, C_{95 \%}=-0.11$ to -0.02 ) with CIs that do not include zero. An interval estimate of this index presents "an inferential test as whether the indirect effect depends linearly on the moderator" (Hayes, 2015, p. 15). In the case of our model with a dichotomous moderator, it is also a test for differences between the conditional indirect effects between the two groups. For satisfaction, we did not find a moderated mediation effect of the resident/non-resident factor. Thus, H4a and $\mathrm{H} 4 \mathrm{~b}$ are supported by the data, while $\mathrm{H} 4 \mathrm{c}$ is rejected.

\section{General discussion}

Our studies contribute to different academic discussions in place and tourism research: First, study 1 provides empirical evidence for the claim that positive place attitude (i.e., place satisfaction, identification, and attachment) and place behaviour (i.e., word-of-mouth) are positively associated with a higher brand complexity - for residents. This validates the theoretical assumption of Zenker and Petersen's (2014) concept of residentcity identification. In line with Social Identity Theory (Tajfel \& Turner, 1986), this relationship is mediated by the determinants of identification, namely attractiveness of identification, identity fit, and optimal distinctiveness-showing that Social Identity Theory can also be translated to places and deliver a thorough approach of explaining different place effects (see also Palmer et al., 2013). These results are also in line with Sirgy's et al. (2005) theoretical assumptions, arguing that a higher match between the self-concept and the residential occupant image makes that place more attractive.

Another interesting result is that the different attitude concepts presented different relationship strengths with the behaviour measurements: For instance, in study 1 (focusing on the residents) it seems that identification has a much stronger relationship with word-of-mouth than attachment and satisfaction. This effect of place satisfaction on word-of-mouth is in line with earlier results from Zenker and Rütter (2014), further validating our results here. Surprisingly, place attachment showed the weakest relationship in this regard, thus raising questions about the extensive research around this construct (Altman \& Low, 1992; Knez, 2005; Lewicka, 2011) and the comparably smaller attention given to identification in the research literature.

Third, the study contributes to the field of place advocacy and place ambassadorship (Braun et al., 2013; Palmer et al., 2013), since it can serve as one explanation of the motivation of residents becoming a place brand ambassador. Rehmet and Dinnie (2013) argue in their qualitative study of active brand ambassadors in Berlin (Germany), that not commitment with the brand but the stakeholders' personal interest in enhancing the reach and exposure of their individual projects are the driver of place brand advocacy (i.e., positive word-of-mouth). In our studies attachment/ commitment also show a relatively low impact on positive place word-of-mouth, while identification is the strongest driver of place advocacy.

The results of the second study show a positive relationship between brand complexity with satisfaction, commitment and identification, leading to a higher intention of positive place-wordof-mouth for all target groups (with similar effect sizes for satisfaction, identification and attachment/commitment on positive word-of-mouth like in study 1). Additionally, our moderation tests suggests that this relationship between brand complexity and identification and commitment is even stronger for the internal target audience (current residents) than for visitors (non-residents), supporting the conclusion that place brands should not be too much simplified in general and a place brand should (at least) differ for internal and external target audiences. Having said this, we still agree with Zenker and Braun (2010) and Hanna and Rowley (2015) that you cannot see both concepts disjointedly. One brand (a touristic and a potential residential brand) would also influence the other target group especially since residents work as brand ambassador and are part of the place brand as such (Braun et al., 2013). 
However, in sum, these studies make an important contribution to tourism theory: through the novel application of Social Identity Theory, they explain the requirements of place identification, the positive outcome of identification, and the differences for residents and visitors in this relationship.

\subsection{Theoretical contributions and future research}

The Social Identity Theory (Tajfel \& Turner, 1986) is beneficial for both general consumer research (e.g., Reed II, 2002) and tourism research (e.g., Palmer et al., 2013). It strongly influences the current understanding of consumer behaviour and gives valuable insights into understanding the 'why' of consumers' actions. As illustrated in this paper, the theory also serves the field of place and destination branding and the issue of brand complexity.

Nevertheless, this paper is only a first step in exploring the issue of brand complexity. Indeed, several questions remain: First, it has not been empirically tested whether different levels of perceived brand complexity lead to higher identification. One could argue that too much perceived brand complexity could lower the distinctiveness of a place, as the features of said place would seem too similar to other places (since all places fulfil more or less the same purpose, e.g., living, leisure, and workrelated aspects). Given that people evaluate stimuli (such as cities) within and between different categories (Zenker, 2011), increasing the perceived complexity could make it harder to find different categories (cities) to compare, and thus lower the metacontrast ratio (Turner, Hogg, Oakes, Reicher, \& Wetherell, 1987). This would result in a New York resident being perceived as no different from a resident of Houston, Texas.

Moreover, a higher perceived brand complexity could negatively influence place identification by increasing customers' feeling of uncertainty. As Hogg (2007) points out, people have a need to reduce uncertainty and therefore could react negatively to an increasing brand complexity. Furthermore, Brewer (1991) suggests that people have a need for assimilation (up to a point). Both the reduction of uncertainty and the increase in assimilation could be hampered by places expanding their perceived brand complexity too much. Thus, a U-shaped model (i.e., where identification increases alongside complexity up to a point, then decreases again) might be more appropriate than a linear one.

Furthermore, a deeper analysis regarding the type of complexity is needed. While in their theoretical paper Zenker and Petersen (2014) propose that complexity consist of different types such as quantity, ambiguity (rich and poor at the same time), or entropy (organized versus chaotic), also other factors could be relevant such as variability (different perceptions of New York as a whole and sub-areas like Queens). Thus, complexity is theoretically still not comprehensively derived in place studies.

Finally, it is important to consider the situation in which information is processed. Stress, distraction or negative affect might limit the ability to synthesize information, which is a highly complex task on a cognitive level. Again, a differentiation between inhabitants and visitors seems important, since tourists mostly perceive the place on a different (lower) stress level than average inhabitants. In addition, cultural differences could play an interesting role here. More empirical work is thus needed to test different levels of brand complexity at different levels of cognitive and affective distraction, thereby addressing the challenge of optimal brand complexity in place and destination branding.

\subsection{Practical implications}

The results suggest that a higher place brand complexity is related to a higher identification with the place. This higher identification is a precondition for becoming a place brand ambassador (Braun et al., 2013; Rehmet \& Dinnie, 2013), making these results highly relevant for practitioners-even for those solely focusing on tourists as target audiences. They highlight the need for a place brand-architecture that embraces complexity featuring, for example, different target group-specific sub-brands in combination with a place umbrella brand in order to convey a message that is more heterogeneous and complex (Zenker and Braun, 2010). A place's sub-brand for its residents could include an image that better reflects demographical heterogeneity. Giving all social groups the opportunity to participate in how a place brand is communicated supports the democratic process and may help to empower (status) minorities, while still being attractive and effective as a places destination brand.

In contrast, place brand communication can become fuzzy if the brand is too complex. For instance, a city might lose its distinction among other cities if the complexity of place brand communication renders the unique identity of the place somewhat vague. This issue is particularly relevant for tourists and other external target audiences, who prefer simple place brand communication based on stereotypes (Zenker \& Beckmann, 2012). Therefore, place marketers are challenged to find a manageable degree of brand complexity and then adjust this level to the target group in question.

However, examples from place branding practice with a too simple brand communication that is exclusively aimed at external target audience, jeopardizes the support for the place branding effort within the city community. For instance, the metropolitan region of Hamburg defines itself stereotypically as a 'city on the waterfront,' inhabited by 'creative' and 'wealthy' people, that offers a wide variety of cultural amenities such as 'musicals' to tourists and desired new residents. While this communicated place brand matches the image held by Hamburg's external target audiences, it disregards the perceptions of the current residents (Zenker \& Beckmann, 2012). Even though without doubt this campaign has worked very well for tourism, the city's residents could not identify with the communicated place brand. The city witnessed public protests against Hamburg's marketing activities as the successful attraction of the 'creative class' and tourists resulted in gentrification of several city districts (Zenker \& Beckmann, 2012). The protest was labelled 'Not in our Name' and included a street protest of Hamburg residents and other creative activities. Residents did not wanted to live under forced brand values such as 'creative' and thus were unable to identify with the city's communicated place brand. This resulted in distrust between a considerable part of the inhabitants and the city's marketing organization. This anecdotal evidence illustrates the importance of a differentiated and more complex place brand communication tailored to target groups. Secondly, it shows that a full separation of the destination branding approaches from the other target groups (such as residents) could be also dangerous.

Hamburg's brand communication could benefit from a brandarchitecture that accommodates complexity by means of developing target group-specific sub-brands as well a city umbrella brand. In this case, the city could design more or less complex subbrands for its internal and external audiences, respectively. Such variety could generate communication that is more authentic and inspire all target groups to better identify with the Hamburg brand. The same may hold true for other cities, destinations or perhaps 
even nations.

However, a narrowed perspective that focuses solely on tourists, without incorporating residents, is not the optimal solution. As indicated earlier, the disciplinary differentiation between tourism and place marketing seems outdated. This research indicates that tourists and residents are jointly influenced by place branding, so failing to incorporate both target groups can harm the efficiency of any branding strategy. Thus, our studies support the increasingly common approach used by place managers, whereby the tourism brand incorporates the target group of (potential) residents, or the tourism organization becomes a unit in the larger place marketing effort.

\subsection{Limitations and future studies}

Beside the merits of this study, results should not be overstated and seen only as a first step to explore the phenomenon of brand complexity. Both studies did not use a representative sample. For the first study, a research panel from a university and for the second study a professional panel provider was used. Both studies were conducted in Germany with a German sample (thus the nonresidents can be regarded as potential domestic visitors). Future studies should include more different target groups (internal: with different resident groups; external: with different countries) to test if the positive effect of brand complexity can be also found for more target groups. Furthermore, the construct of brand complexity itself was measured on a general level, while future studies could include the different parts of complexity (e.g., its quantity and qualities), or assume a non-linear relationship. Finally, the different strengths of effects for identification, attachment, and satisfaction found here call for more critical reflection: future studies could focus on these different concepts and further investigate how they are interrelated.

\section{Conclusions}

This article seeks to develop a broader understanding of how destination and place branding affects both residents and tourists, and what role the complexity of such a brand plays in place identification. It translated concepts (such as complexity, identification and commitment) and the Social Identity Theory from related disciplines to the field of tourism. In doing so, it put a spotlight on the close relationship between destination and place branding-that is still not common sense in tourism literature. Finally, we tried to make a statement that brand complexity is valuable for place brands in general (including the destination brand), but that the place brand for residents needs even more complexity than a destination brand, while it remains valuable if both are integrative parts of an overall place brand.

\section{Acknowledgments}

Sebastian Zenker wants to thank the Deutsche Forschungsgemeinschaft (Grant number: ZE933/1-1) DFG (German Research Council) for the funding of this project. Furthermore, the authors thank Natascha Rütter for her helpful comments on previous versions of this manuscript - as well as the anonymous reviewers.

\section{Appendix. Measures of model constructs}

\begin{tabular}{|c|c|c|c|}
\hline Construct & Item & Label & Source \\
\hline \multirow{3}{*}{ Brand Complexity } & The city you live in is complex & BC1 & Cox \& Cox, 1988* \\
\hline & The city you live in is multi-faceted & $\mathrm{BC} 2$ & \\
\hline & The city you live in has different sides & $\mathrm{BC} 3$ & \\
\hline Identity Fit & How strongly do you fit to the city you are living in?** & & Brown \& Rafaeli, 2007* \\
\hline \multirow[t]{3}{*}{ Attractiveness of Identification } & The city you live in is good & AI1 & Osgood et al., 1957 \\
\hline & The city you live in is positive & $\mathrm{AI} 2$ & \\
\hline & The city you live in is favourable & $\mathrm{AI} 3$ & \\
\hline \multirow[t]{3}{*}{ Optimal Distinctiveness } & The city you live in is unique & OD1 & Bhattacharya \& Sen, 2003* \\
\hline & The city you live in is distinctive & OD2 & \\
\hline & The city you live in is very different from other cities & OD3 & \\
\hline \multirow[t]{4}{*}{ Identification } & If someone criticizes the city I live in, it feels like he criticize me & ID1 & Bhattacharya \& Sen, 2003* \\
\hline & I am very interested in what others think about the city I live in & ID2 & \\
\hline & A success of my city feels like my own success & ID3 & \\
\hline & If someone talks positively about the city I live in, it feels like a compliment & ID4 & \\
\hline \multirow[t]{3}{*}{ Satisfaction } & All together I am satisfied with the city I live in & SA1 & Zenker et al., 2013 \\
\hline & In general I like living in this city & SA2 & \\
\hline & In general I did not like the city I live in [R] & SA3 & \\
\hline \multirow[t]{3}{*}{ Attachment } & The place feels like home & AT1 & Zenker \& Gollan, 2010 \\
\hline & There are a lot of things that keep me in the place & AT2 & \\
\hline & There is no other place I would rather live in & AT3 & \\
\hline \multirow[t]{4}{*}{ Word-of-Mouth } & I have recommended this brand to lots of people & WM1 & Carroll \& Ahuvia, 2006* \\
\hline & I 'talk up' this place to my friends & WM2 & \\
\hline & I spread the good-word about this place & WM3 & \\
\hline & I give this place positive word-of-mouth advertising & WM4 & \\
\hline \multirow[t]{3}{*}{ Commitment } & I could not easily bond to another place like [CITY] & CT1 & Allen \& Meyer, 1990* \\
\hline & I hardly feel connected to $[\mathrm{CITY}][R]$ & CT2 & \\
\hline & I do not feel as a part of 'the family' in [CITY] [R] & CT3 & \\
\hline
\end{tabular}

Note: * adopted from; ${ }^{* *}$ measured with a VENN-diagram; $[\mathrm{R}]=$ reversed coded. 


\section{References}

Abrams, D. (2009). Social identity on a national scale: Optimal distinctiveness and young people's self-expression through musical preference. Group Processes and Intergroup Relations, 12(3), 303-317.

Allen, N. J., \& Meyer, J. P. (1990). The measurement and antecedents of affective, continuance and normative commitment to the organization. Journal of Occupational Psychology, 63(1), 1-18.

Altman, I., \& Low, S. M. (1992). Place attachment. New York, NY: Plenum.

Anholt, S. (2009). Should place brands be simple? Place Branding and Public Diplomacy, 5(2), 91-96.

Arbuckle, J. L., \& Wothke, W. (1999). AMOS 4.0 users' guide. Chicago: SmallWaters Corp.

Ashworth, G., \& Voogd, H. (1990). Selling the City: Marketing approaches in public sector urban planning. London: Belhaven.

Baumeister, R. F., \& Leary, M. R. (1995). The need to belong: Desire for interpersonal attachments as a fundamental human motivation. Psychological Bulletin, 117(3), 497-529.

Bergami, M., \& Bagozzi, R. P. (2000). Self-categorization, affective commitment and group self-esteem as distinct aspects of social identity in the organization. British Journal of Social Psychology, 39(4), 555-577.

Bettman, J., Frances, L. M., \& Payne, J. W. (1998). Constructive consumer choice processes. Journal of Consumer Research, 25(3), 187-217.

Bhattacharya, C. B., \& Sen, S. (2003). Consumer-company identification: A framework for understanding consumers' relationships with companies. Journal of Marketing, 67(April), 76-88.

Braun, E. (2008). City Marketing: Towards an integrated approach. Rotterdam: Erasmus Research Institute of Management (ERIM).

Braun, E. (2012). Putting city branding into practice. Journal of Brand Management, 19(4), 257-267.

Braun, E., Kavaratzis, M., \& Zenker, S. (2013). My city - My brand: The different roles of residents in place branding. Journal of Place Management and Development, 6(1), 18-28.

Brewer, M. B. (1991). The social self: On being the same and different at the same time. Personality and Social Psychology Bulletin, 17(5), 475-482.

Brewer, M. B. (2003). Optimal distinctiveness, social identity, and the self. In M. R. Leary, \& J. P. Tangney (Eds.), Handbook of self and identity (pp. 480-491). New York, NY: Guilford Publications.

Brown, G., \& Rafaeli, E. (2007). Components of self-complexity as buffers for depressed mood. Journal of Cognitive Psychotherapy, 21(4), 310-333.

Cai, L. A. (2002). Cooperative branding for rural destinations. Annals of Tourism Research, 29(3), 720-742.

Campbell, D. T., \& Fiske, D. W. (1959). Convergent and discriminant validation by the multitrait-multimethod matrix. Psychological Bulletin, 56(2), 81-105.

Carroll, B. A., \& Ahuvia, A. C. (2006). Some antecedents and outcomes of brand love. Marketing Letters, 17(2), 79-89.

Cox, D. S., \& Cox, A. D. (1988). What does familiarity breed? Complexity as a moderator of repetition effects in advertisement evaluation. Journal of Consumer Research, 15(1), 111-116.

Fleury-Bahi, G., Félonneau, M.-L., \& Marchand, D. (2008). Processes of place identification and residential satisfaction. Environment and Behavior, 40(5), 669-682.

Fornell, C. G. \& Larcker, D. F. (1981). Evaluating structural equation models with unobservable variables and measurement error. Journal of Marketing Research, 18(1), 39-50.

Freire, J. R. (2009). Local People' a critical dimension for place brands. Journal of Brand Management, 16, 420-438.

Gertner, D. (2011). Unfolding and configuring two decades of research and publications on place marketing and place branding. Place Branding and Public Diplomacy, 7(2), 91-106.

Gross, M. J., \& Brown, G. (2006). Tourism experiences in a lifestyle destination setting: The roles of involvement and place attachment. Journal of Business Research, 59(6), 696-700.

Hanna, S., \& Rowley, J. (2015). Towards a model of the place brand web. Tourism Management, 48, 100-112.

Hayes, A. F. (2013). Introduction to mediation, moderation, and conditional process analysis: A regression-based approach. New York, NY: The Guilford Press.

Hayes, A. F. (2015). An index and test of linear moderated mediation. Multivariate Behavioral Research, 50(1), 1-22.

Hayes, A. F., \& Preacher, K. J. (2012). Statistical mediation analysis with a multicategorical independent variable. available at http://www.afhayes.com/public/ hp2012.pdf Accessed 15.12.13.

Henseler, J., Ringle, C. M., \& Sarstedt, M. (2015). A new criterion for assessing discriminant validity in variance-based structural equation modeling. Journal of the Academy of Marketing Science, 43, 115-135.

Hogg, M. A. (2000). Subjective uncertainty reduction through self-categorization: A motivational theory of social identity processes. European Review of Social Psychology, 11, 223-255.

Hogg, M. A. (2007). Uncertainty-identity theory. Advances in Experimental Social Psychology, 39, 69-126.

Hogg, M. A., \& Abrams, D. (1988). Social identifications: A social psychology of intergroup relations and group processes. London: Routledge.

Hu, L.-T., \& Bentler, P. M. (1999). Cutoff criteria for fit indexes in covariance structure analysis: Conventional criteria versus new alternatives. Structural Equation
Modeling: A Multidisciplinary Journal, 6(1), 1-55.

Insch, A., \& Florek, M. (2010). Place satisfaction of city residents: Findings and implications for city branding. In G. Ashworth, \& M. Kavaratzis (Eds.), Towards effective place brand management - Branding European cities and regions ( $\mathrm{pp}$ 191-204). Cheltenham: Edward Elgar Publishing.

Janiszewski, C., \& Meyvis, T. (2001). Effects of brand logo complexity, repetition, and spacing on processing fluency and judgment. Journal of Consumer Research, 28(1), 18-32.

Kaplan, M. D., Yurt, O., Guneri, B., \& Kurtulus, K. (2010). Branding places: Applying brand personality concept to cities. European Journal of Marketing, 44(9/10), 1286-1304.

Kavaratzis, M. (2004). From city marketing to city branding: Towards a theoretical framework for developing city brands. Place Branding and Public Diplomacy, $1(1), 58-73$.

Kavaratzis, M., \& Ashworth, G. J. (2007). Partners in coffeeshops, canals and commerce: Marketing the city of Amsterdam. Cities, 24(1), 16-25.

Keller, K. L. (1993). Conceptualizing, measuring, and managing customer-based brand equity. Journal of Marketing, 57(January), 1-22.

Keller, K. L. (2003). Brand synthesis: The multidimensionality of brand knowledge Journal of Consumer Research, 29(4), 595-600.

Kerr, G. (2006). From destination brand to location brand. Journal of Brand Management, 13(4/5), 276-283.

Kline, R. B. (2011). Principles and practice of structural equation modeling. New York, NY: The Guilford Press.

Knez, I. (2005). Attachment and identity as related to a place and its perceived climate. Journal of Environmental Psychology, 25(2), 207-218.

Lewicka, M. (2011). Place attachment: How far have we come in the last 40 years? Journal of Environmental Psychology, 31(3), 207-230.

Linville, P. W. (1985). Self-complexity and affective extremity: don't put all of your eggs in one cognitive basket. Social Cognition, 3(1), 94-120.

Linville, P. W. (1987). Self-complexity as a cognitive buffer against stress-related illness and depression. Journal of Personality and Social Psychology, 52(4), $663-676$.

Lowrey, T. M. (1998). The effects of syntactic complexity on advertising persuasiveness. Journal of Consumer Psychology, 7(2), 187-206.

Lussier, D. A., \& Olshavsky, R. W. (1979). Task complexity and contingent processing in brand choice. Journal of Consumer Research, 6(2), 154-165.

Merrilees, B., Miller, D., \& Herington, C. (2012). Multiple stakeholders and multiple city brand meanings. European Journal of Marketing, 46(7/8), 1032-1047.

Mullen, B., \& Hu, L.-T. (1989). Perceptions of ingroup and outgroup variability: A meta-analytic integration. Basic and Applied Social Psychology, 10(3), 233-252.

Osgood, C. E., Suci, G. J., \& Tannenbaum, P. (1957). The measurement of meaning. Urbana: University of Illinois Press.

Oyserman, D., Coon, H. M., \& Kemmelmeier, M. (2002). Rethinking individualism and collectivism: Evaluation of theoretical assumptions and meta-analyses. Psychological Bulletin, 128(1), 3-72.

Palmer, A., Koenig-Lewis, N., \& Jones, L. E. M. (2013). The effects of residents' social identity and involvement on their advocacy of incoming tourism. Tourism Management, 38, 142-151.

Park, S.-Y., \& Petrick, J. F. (2006). Destinations' perspectives of branding. Annals of Tourism Research, 33(1), 262-265.

Phillips, D. R., Cheng, K. H. C., Yeh, A. G. O., \& Sui, O.-L. (2010). Person-environment (P-E) fit models and psychological well-being among older persons in Hong Kong. Environment and Behavior, 42(2), 221-242.

Pieters, R., Wedel, M., \& Batra, R. (2010). The stopping power of advertising: Measures and effects of visual complexity. Journal of Marketing, 74(5), 48-60.

Podsakoff, P. M., MacKenzie, S. B., Lee, J.-Y., \& Podsakoff, N. P. (2003). Common method biases in behavioural research: A critical review of the literature and recommended remedies. Journal of Applied Psychology, 88(5), 879-903.

Qu, H., Kim, L. H., \& Im, H. H. (2011). A model of destination branding: Integrating the concepts of the branding and destination image. Tourism Management, 32 465-476.

Rafaeli-Mor, E., \& Steinberg, J. (2002). Self-complexity and well-being: A review and research synthesis. Personality and Social Psychology Review, 6(1), 31-58.

Rapoport, A., \& Hawkes, R. (1970). The perception of urban complexity. Journal of the American Institute of Planners, 36(2), 106-111.

Reed II, A. (2002). Social identity as a useful perspective for self-concept-based consumer research. Psychology \& Marketing, 19(3), 235-266.

Rehmet, J., \& Dinnie, K. (2013). Citizen brand ambassadors: Motivations and perceived effects. Journal of Destination Marketing \& Management, 2(1) $31-38$.

Satorra, A., \& Bentler, P. M. (1994). Corrections to standard errors in covariance structure analysis. In A. Von Eye, \& C. C. Clogg (Eds.), Latent variable Analysis: Applications to developmental research (pp. 399-419). Thousand Oaks, CA: Sage.

Scammon, D. L. (1977). Information load and consumers. Journal of Consumer Research, 4(3), 148-155.

Sharpley, R. (2014). Host perceptions of tourism: A review of the research. Tourism Management, 42, 37-49.

Sheldon, K. M., \& Bettencourt, B. A. (2002). Psychological need-satisfaction and subjective well-being within social groups. British Journal of Social Psychology, 41, 25-38.

Showers, C. (1992). Compartmentalization of positive and negative self-knowledge: Keeping bad apples out of the bunch. Journal of Personality and Social Psychology, 62(6), 1036-1049. 
Sirgy, M. J., Grzeskowiak, S., \& Su, C. (2005). Explaining housing preference and choice: The role of self-congruity and functional congruity. Journal of Housing and the Built Environment, 20, 329-347.

Stedman, R. C. (2002). Towards a social psychology of place: Predicting behavior from place-based cognitions, attitude, and identity. Environment and Behavior 34(5), 561-581.

Stokburger-Sauer, N. (2010). Brand community: Drivers and outcome. Psychology \& Marketing, 27(4), 347-368.

Stokburger-Sauer, N., Ratneshwar, S., \& Sen, S. (2012). Drivers of consumerbrand identification. International Journal of Research in Marketing, 29(4), 406-418.

Swaminathan, V. (2003). The impact of recommendation agents on consumer evaluation and choice: The moderating role of category risk, product complexity, and consumer knowledge. Journal of Consumer Psychology, 13(1\&2), 93-101.

Tajfel, H., \& Turner, J. C. (1986). Social identity theory of intergroup behavior. In W. G. Austin, \& S. Worchel (Eds.), The social psychology of intergroup behavior (Vol. 2, pp. 7-24). Monterey, CA: Brooks/Cole.

Teo, T. S. H., Srivastava, S. C., \& Jiang, L. (2008). Trust and electronic government success: An empirical study. Journal of Management Information Systems, 25(3), 99-132.

Turner, J. C., Hogg, M. H., Oakes, P. J., Reicher, S. D., \& Wetherell, M. S. (1987) Rediscovering the social group. A self-categorization theory. New York, NY: Basil Blackwell.

Voorhees, C. M., Brady, M. K., Calantone, R., \& Ramirez, E. (2016). Discriminant validity testing in marketing: An analysis, causes for concern, and proposed remedies. Journal of the Academy of Marketing Science, 44, 119-134.

Wang, S., \& Xu, H. (2015). Influence of place-based senses of distinctiveness, continuity, self-esteem and self-efficacy on residents' attitude towards tourism. Tourism Management, 47, 241-250.

Xiong, L., King, C., \& Piehler, R. (2013). That's not my job”: Exploring the employee perspective in the development of brand ambassadors. International Journal of Hospitality Management, 35, 348-359.

Zenker, S. (2011). How to catch a city? The concept and measurement of place brands. Journal of Place Management and Development, 4(1), 40-52.

Zenker, S.,\& Braun, E. (2010). Branding a city - a conceptual approach for place branding and place brand management. In Proceedings of the 39th European Marketing Academy Conference, Copenhagen, Denmark, available at www. placebrand.eu/publications/ Accessed 26.06.14.

Zenker, S., \& Beckmann, S. C. (2012). Place branding: The issue of a narrowed tourism perspective. In R. H. Tsiotsou, \& R. E. Goldsmith (Eds.), Strategic marketing in tourism services (pp. 63-78). Bingley: Emerald.

Zenker, S., \& Gollan, T. (2010). Development and implementation of the resident migration scale (ReMiS): Measuring success in place marketing. In E. H. Witte, T. Gollan (Eds.), Sozialpsychologie und Ökonomie (pp. 156-172). Lengerich: Pabst Verlag.

Zenker, S., Gollan, T., \& Van Quaquebeke, N. (2014). Using polynomial regression analysis and response surface methodology to make a stronger case for value congruence in place marketing. Psychology \& Marketing, 31(3), 184-202.

Zenker, S., \& Petersen, S. (2014). An integrative theoretical model for improving resident-city identification. Environment and Planning A, 46(3), 715-729.

Zenker, S., Petersen, S., \& Aholt, A. (2013). The citizen satisfaction index (CSI):
Evidence for a four basic factor model in a German sample. Cities, 31(April), 156-164.

Zenker, S., \& Rütter, N. (2014). Is satisfaction the key? The role of citizen satisfaction, place attachment and place brand attitude on positive citizenship behavior. Cities, 38(June), 11-17.

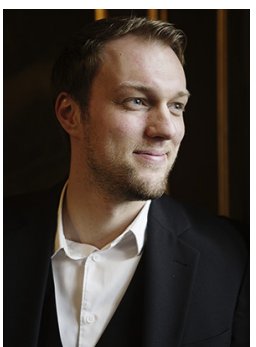

Sebastian Zenker, $\mathrm{PhD}$, is the corresponding author and an assistant professor at the Copenhagen Business School (CBS). His current research interests are mainly the measurement of place brands and place brand perceptions with the special target group of residents. His work was presented at various international conferences, book chapters, peer-reviewed journals, e.g., the Journal of Business Ethics, Environment and Planning A, or the International Journal of Research in Marketing. Sebastian Zenker can be contacted at: Department of Marketing, Solbjerg Plads 3C, 3rd floor, DK-2000 Frederiksberg, Denmark; Email: zenker@placebrand.eu.

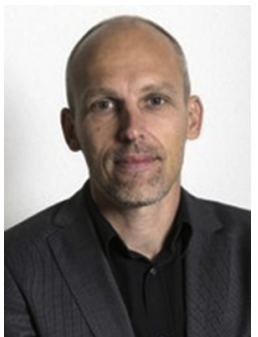

Erik Braun, $\mathrm{PhD}$, is a senior researcher and lecturer in urban economics, place marketing and real estate at Erasmus University Rotterdam. His current place marketing research interest concern the application of marketing and branding concepts by cities and regions, place brand management, place brand perceptions and the governance of place marketing. His research is published in books, book chapters and academic journals including Cities, Environment and Planning C, Public Administration Review, and Urban Studies. Erik Braun can be contacted at: Erasmus School of Economics, Erasmus University Rotterdam, Room H16-17, P.O. Box 1738, 3000 DR Rotterdam, The Netherlands; braun@ese.eur.nl.

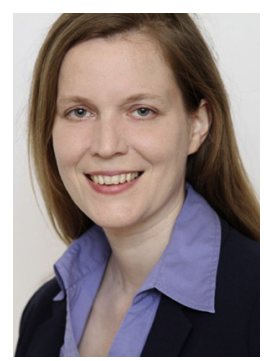

Sibylle Petersen, $\mathrm{PhD}$, is a post-doctoral researcher at the University of Leuven, Department of Psychology, working on identity and complexity. Her work was published for instance in Psychological Science or Environment and Planning $A$. She can be contacted at: University of Leuven, Tiensestraat 102, BE-3000 Leuven, Belgium; Email: sibylle. petersen@psy.kuleuven.be. 